\title{
Changing Regionalism in South-East Asia: some theoretical and practical aspects ${ }^{\#}$
}

\section{Zuzana Stuchlíková*}

With increasing interdependence of national economies in a globalizing world economy, regional economic cooperation (today especially among developing countries) becomes more important for national development. Regional strategies may to some extent fill the possible gaps in the system of the global economic governance as well.

There are many sophisticated discussions about the possible effects of such cooperation, whose results are ambiguous. However, it is evident that Regional Trade Agreements $\left(\right.$ RTAs) ${ }^{1}$ have been increasingly transforming international trade, especially since the second half of the 1990s. This period of dynamic regional integration processes is called 'new regionalism'. Among others, this term denotes a departure from multilateralism because of a growing sense of frustration of some countries from the slow pace of multilateral trade negotiations in the World Trade Organization (WTO).

Regional cooperation occurs in various forms and degrees. In general, RTAs promote trade and other cross-border linkages among their member countries through the elimination of tariffs and other trade and economic barriers. There are many classifications of RTAs (see Cihelková et. al, 2007). A distinction is made e.g. between policy-induced and market-driven integration. Policy-induced integration (called regionalism) involves formal economic cooperation arrangements to liberalize or facilitate trade on a regional basis. The Free Trade Agreement (FTA) is the most frequent institutional form of these regional arrangements. On the other hand, market-driven integration (called regionalization) is spurred by regional growth dynamics, the emergence of international production networks and related flows of foreign direct investments. The forms of cooperation among countries depend on many internal and external factors and conditions - on the specific geographical, historical, cultural and political circumstances in the region, on the current economic policy directions both at the national and global levels, etc.

Institutional (or policy-induced) economic regionalism has come late to South-East Asia $^{2}$, especially compared to Western Europe. South-East Asia is now growing dynami-

\footnotetext{
This paper has been worked out within the framework of the Czech Science Agency Project "Regionalism and multilateralism: foundations of the new world trade order?" No. 402/07/0253, and the Research Plan of the Faculty of International Relations "Governance in context of globalised economy and society" No. MSM 6138439909.

* Ing. Zuzana Stuchlíková - research fellow; Department of World Economy, Faculty of International Relations, University of Economics, Prague, nám. W. Churchilla 4, 13067 Praha 3, Czech Republic; <stuchliz@vse.cz>.

1 In the World Trade Organization terminology, RTAs have more general than geographical meaning. RTAs may be concluded among countries that do not necessarily belong to the same geographical region.

2 Identifying the region of 'South-East Asia' may be difficult because there are many varied definitions of the region in the literature. According to the United Nations Economic and Social Commission for Asia and the Pacific (ESCAP) or Asian Development Bank (ADB), South-East Asia contains: Brunei Darussalam, Cambodia, Indonesia, Lao People's Democratic Republic, Malaysia, Myanmar, Philippines, Singapore, Thailand, Viet Nam and Timor-Leste. East Asia (or North-East Asia) includes: People's Republic of China, Hong Kong, Japan, Republic of Korea, DPR Korea, Mongolia and Taipei. Trying to simplify, I use the term 'South-East Asia' for all the mentioned Asian countries together in this study (unless it is stated otherwise-according to varying statistics).
} 
cally. The regionalism trends in the region are also changing rapidly. There are many new initiatives that cover an ever-increasing portion of the region. With respect to the spread of membership, Asian countries still prefer bilateral agreements (this phenomenon is called bilateralism), which are easier to arrange and more effective than multilateral agreements. There are only few multilateral integration schemes in the region. More importantly, the newly concluded agreements go beyond reduction of elimination of tariffs and non-tariff barriers, as is characteristic for FTAs.

The motives, objectives and approaches of major economic powers of the region, i.e. Japan and China, are also changing. Japan has not participated in any preferential regional agreement until 2002. Nevertheless, Japan's FTA negotiations have gained momentum in recent years. Today, Japan is promoting rule making appropriate for the diverse range of economic relations through Economic Partnership Agreements (EPAs). These agreements should complement the functions of the WTO that is loosing its effectiveness. Japan is a key actor in South-East Asia integration. However, it has to compete for this position more and more with the boosting Chinese economy which has emerged as a major economic power of the region. China has contributed significantly to the accelerating pace of intraregional trade since the late 1980s. It is also concluding many new agreements covering increasing proportion of its foreign trade.

This paper aims to answer following questions: What are the most important trends in contemporary South-East Asia regionalism with respect to some aspects of the new regionalism theory? What is the position of the traditional economic power of the region, i.e. Japan, towards regionalism in Asia today? Since the issue is very complex and complicated, the attention will be paid only to some most interesting and discussed trends of Asian regionalism.

\section{New Regionalism in South-East Asia}

The region of South-East Asia is distinct from other Asian regions in many ways; and it is very inwardly heterogeneous (see Tab. 1). Not only does the region contain every major religion and form of government, but it is also distinguished by huge disparities in wealth distribution and in the underlying economic, social and demographic circumstances of the region's economies. The region's economies are still at different levels of industrialization and economic development, levels of nominal GDP and GDP per capita, ranging from high income countries (Japan, Hong Kong, Republic of Korea, Singapore) to low income or even to the least developing countries ${ }^{3}$ (Cambodia, LAO PDR, Myanmar, Timor-Leste). The region contains two major economic, political and cultural powers China and Japan - which have exerted a long-term influence on other South-East Asia countries.

In the South-East Asia integration process, stages of industrialization and regional development have been closely interlinked: “... The rapid upgrading of economic activity from resource-based and labour intensive industries to increasingly sophisticated manufactures in the leading economies opened up opportunities for their less developed neighbours to enter the regional division of labour by expanding their less demanding, lower skill, labour-intensive activities that could no longer be competitively supplied by the front

3 'The Least Developed Countries (LDCs)' is a category used by the United Nations for low income countries (GDP per capita under 750 USD) that have weak human assets and vulnerable economy (and population not greater than 75 million). These poor countries are given special international treatment, concessions and support measures by high income countries and international organizations. 
runners..." (UNCTAD, 2007b, p. 91). In this 'flying-geese' process, trade and FDI served as vehicles for redistributing comparative advantage across the whole region.

Japan has acted mostly as an economic model thanks to highly successful industrialization and modernization process starting with Meiji reforms in the late 19th century and amplifying in the second half of the 20th century. Asian economic development has always been led by a forerunner. After Japan, it was the four tigers' in the 1970s (Hong Kong, ROK, Singapore and Taiwan). During the 1980s, the members of the ASEAN joined the race; and in the 1990s China (and India) assumed the leadership in the Asian economic dynamism. It is increasingly contributing to shaping the pattern of regional integration in South-East Asia. This catch-up mentality is a unique feature of the region's economic development.

Tab. 1: South-East Asia - selected data, 2005

\begin{tabular}{||l|c|c|c|c||}
\hline \multicolumn{1}{|c|}{ Region/country } & $\begin{array}{c}\text { Area } \\
\text { (000 sq km) }\end{array}$ & $\begin{array}{c}\text { Population } \\
\text { (million) }\end{array}$ & $\begin{array}{c}\text { Nominal GDP } \\
\text { (US\$ bn) }\end{array}$ & $\begin{array}{c}\text { GDP per } \\
\text { capita (US\$) }\end{array}$ \\
\hline \hline North-East Asia & $11,113.0$ & $1,402.8$ & $3,312.0$ & $2,375.0$ \\
\hline- China & $9,327.0$ & $1,298.0$ & $1,981.6$ & $1,227.0$ \\
\hline - Republic of Korea & 99.3 & 48.0 & 787.6 & $13,184.0$ \\
\hline Japan & 365.0 & 127.9 & $4,558.9$ & $35,646.0$ \\
\hline South-East Asia & $4,362.0$ & 565,1 & 882.1 & $1,582.0$ \\
\hline - Indonesia & $1,812.0$ & 228.9 & 281.3 & $1,244.0$ \\
\hline - Malaysia & 329.0 & 26.1 & 130.8 & $5,098.0$ \\
\hline - Philippines & 298.0 & 86.3 & 97.6 & $1,155.0$ \\
\hline - Singapore & 1.0 & 4.4 & 116.8 & $26,985.0$ \\
\hline - Thailand & 511.0 & 63.4 & 176.6 & $2,803.0$ \\
\hline - Viet Nam & 325.0 & 86.2 & 45.7 & 625.0 \\
\hline World & $133,841.3$ & $6,592.9$ & $44,475.2$ & $6,827.0$ \\
\hline
\end{tabular}

Notes: North-East Asia refers to China, Hong Kong, Macao, Taiwan, Korea PDR, Republic of Korea, Mongolia. South-East Asia refers to Brunei, Cambodia, Indonesia, Lao PDR, Malaysia, Myanmar, the Philippines, Singapore, Thailand, Timor-Leste and Viet Nam. Data concerning the population and total regions' area refer to 2006.

Source: UNCTAD (2007a), ESCAP (2007, p. 158).

\subsection{Current economic and trade performance}

In general, South-East Asian current economic performance is very good. Ten years after Asian financial crisis, all the crisis countries exceed their precrisis peaks, among other due to far-reaching macroeconomic and structural reforms and institutional changes. But a closer look shows that growth and investment rates have settled on a lower trajectory. On average in 2000-2006, the GDP growth in the five most directly affected countries (Indonesia, Korea, Malaysia, Philippines, and Thailand) ran some 2.5 percentage points behind performance in 1990-1996 (ADB, 2007, p. 17). 
The South-East Asian growth rates of real GDP (see Tab. 2) are very high today, especially for China and other developing countries of the region. The economic growth in developing (or emerging) South-East Asia is supported by high growth in consumption, investment and continued solid exports. Japan's performance is also improving from year to year; it seems to surpass the negative effects of the bubble economy and long stagnation in the 1990s. The outlooks for 2008 and 2009 remain favourable; with growth expected to decline only moderately as foreign demand for Asia's exports is to slow down.

Southeast Asia experienced more rapid growth in trade (both imports and exports) than the world economy did over 1995-2004 (ADB, 2007, p. 17, 86). Despite the absence of formal economic integration at institutional level, the Southeast Asia has also the world's highest rate of growth in intra-regional trade (see Tab. 3). It has grown $8 \%$ per year, i.e. at the same pace as the trade with the rest of the world. China's growth has proven the most dynamic element in intra-regional trade growth. The value of trade between China and other region's countries has grown 14\% per year and it has more than tripled (from $\$ 199$ billion in 1995 to $\$ 655$ billion in 2004) between 1995-2004 (ADB, 2007, p. 87). It is evident that China's growing exports and imports are reshaping trade patterns in Asia and the entire world economy.

Tab. 2: Growth rates of real GDP, 2000-2006 (\% per year)

\begin{tabular}{||l|c|c|c|c|c|c|c||}
\hline \multicolumn{1}{|c|}{ Region/country } & $\mathbf{2 0 0 0}$ & $\mathbf{2 0 0 1}$ & $\mathbf{2 0 0 2}$ & $\mathbf{2 0 0 3}$ & $\mathbf{2 0 0 4}$ & $\mathbf{2 0 0 5}$ & $\mathbf{2 0 0 6}$ \\
\hline \hline North-East and East Asia & 8.2 & 5.6 & 7.6 & 7.3 & 8.4 & 8.1 & 8.5 \\
\hline - China & 8.4 & 8.3 & 9.1 & 10.0 & 10.1 & 10.4 & 10.7 \\
\hline - Republic of Korea & 8.5 & 3.8 & 7.0 & 3.1 & 4.7 & 4.0 & 5.2 \\
\hline - Japan & 2.9 & 0.2 & 0.3 & 1.4 & 2.7 & 1.9 & 2.2 \\
\hline South-East Asia & 6.2 & 2.4 & 4.6 & 5.1 & 6.5 & 5.6 & 5.9 \\
\hline - Indonesia & 4.9 & 3.8 & 4.4 & 4.7 & 5.1 & 5.6 & 5.5 \\
\hline - Malaysia & 8.5 & 0.3 & 4.4 & 5.4 & 7.1 & 5.3 & 5.6 \\
\hline - Philippines & 4.4 & 4.5 & 4.4 & 4.5 & 6.0 & 5.0 & 5.5 \\
\hline - Singapore & 9.6 & -2.0 & 3.2 & 2.9 & 8.7 & 6.4 & 7.6 \\
\hline - Thailand & 4.8 & 2.2 & 5.3 & 7.0 & 6.2 & 4.5 & 5.0 \\
\hline - Viet Nam & 6.8 & 6.9 & 7.1 & 7.3 & 7.8 & 8.4 & 8.2 \\
\hline
\end{tabular}

Notes: Average numbers for North-East and East Asia refers to China, Hong Kong, Mongolia and Republic of Korea. South-East Asia contains these countries: Brunei, Cambodia, Indonesia, Lao PDR, Malaysia, Myanmar, Philippines, Singapore, Thailand, Timor-Leste, Viet Nam.

Source: ESCAP (2007, p. 132). 
Tab. 3: Growth of intra-Asian trade, all sectors, 1995-2004 (\% per year)

\begin{tabular}{||l|c|c|c|c|c||}
\hline Exporter/importer & Japan & China & NIEs & ASEAN-5 & $\begin{array}{c}\text { South-East } \\
\text { Asia }\end{array}$ \\
\hline \hline Japan & - & 16.3 & 2.8 & 0.5 & 4.9 \\
\hline China & 12.9 & - & 13.9 & 19.0 & 14.0 \\
\hline NIEs & 2.7 & 12.8 & 5.8 & 3.9 & 7.6 \\
\hline ASEAN-5 & 4.3 & 21.8 & 4.8 & 12.1 & 7.8 \\
\hline South-East Asia & 6.4 & 14.2 & 6.5 & 5.0 & 8.0 \\
\hline
\end{tabular}

Notes: NIEs are Newly Industrialized Economies of Asia, i.e. (according to ADB) Hong Kong, Republic of Korea, Singapore, and Taipei. ASEAN-5 includes Indonesia, Malaysia, Philippines, Thailand, and Viet Nam.

Source: ADB (2007, p. 87).

The ratio of the ASEAN's ${ }^{4}$ regional exports to total exports increased from $19 \%$ in 1990 to $22 \%$ in 2004 . Trade among the ASEAN +3 countries was larger than intra-ASEAN trade, reaching $35 \%$ in terms of exports in 2004 (Tap, 2005, p. 3). According to some statistics, intra trade represents almost half of that region's total trade today (see Tab. 4). Nevertheless, these ratios are still relatively low compared to the European Union or NAFTA. Intra-regional trade of the EU-25 was $66 \%$ of total exports in 2005 ; NAFTA reached the ratio of $56 \%$ (UNCTAD, 2007a, p. 49).

Tab. 4: Intra-regional trade relations

(Countries' exports within the regions' total exports, \%)

\begin{tabular}{||l|c|c|c|c|c||}
\hline \hline \multicolumn{1}{|c|}{ Region } & 1980-1985 & $\mathbf{1 9 8 6 - 1 9 8 9}$ & $\mathbf{1 9 9 0 - 1 9 9 4}$ & $\mathbf{1 9 9 5 - 1 9 9 9}$ & 2000-2004 \\
\hline \hline East Asia & 32.3 & 32.0 & 38.6 & 41.6 & 43.5 \\
\hline EU & 58.9 & 63.1 & 66.6 & 66.3 & 67.1 \\
\hline NAFTA & 36.7 & 44.2 & 49.9 & 49.8 & 56.0 \\
\hline
\end{tabular}

Notes: Figures represent arithmetical averages for each period. East Asia refers to these countries: Japan, Thailand, Malaysia, Indonesia, the Philippines, Hong Kong, Singapore, Korea and China.

Source: Nakamura and Shinohara (2007, p. 4).

Of course, many economic and social problems remain in the region, especially in the post-crisis Asian economies. However, a detailed analysis of these problems is beyond the scope of this study. It should be also noted that most authors (e.g. Pangestu, 2006, p. 167) point out the necessity of continuation of modernization and reforms in many areas of the economy and society: “... delivering successes in second-generation reform, institutional change, governance, and corruption has become tough in East Asia. The process of expanding political openness and instituting the transition to more stable and mature democracy and the requisite institutions is an even greater challenge." There is a call for new, more effective, democratic and decentralised models of governance in South-East Asia (e.g. Gill and Kharas, 2007). These models should be based on the 'rule of law' instead of

4 The Association of South-East Nations (ASEAN) was established on 8 August 1967 in Bangkok. Today it has 10 member states: Indonesia, Malaysia, Philippines, Singapore, Thailand, Laos, Brunei, Vietnam, Myanmar, and Cambodia. The ASEAN aims at accelerating economic growth, social progress and cultural development in the region and at promoting regional peace and stability. The initiative called ASEAN +3 involve China, Japan and Republic of Korea (for more see below or the ASEAN's Secretariat: www.aseansec.org). 
traditional 'rule of man', which should substantially improve the transparency and accountability of political regimes and economic systems in the region and eliminate especially the prevailing, huge corruption in the region.

\subsection{New impulses and growing number of regional agreements in the region}

The disparities in the mentioned areas and also in the organizing norms and principles of international relations and geopolitical and geoeconomic factors complicate to some extent the processes of regional cooperation and integration. Thus, institutional economic regionalism has come late to South-East Asia. Asian countries did not look for any formal economic cooperation until the second half of the 1990s: "market forces promoted economic integration without agreements in the region and the Asian countries began to have confidence in regional economic dynamism that was independent of legal frameworks" (Munukata, 2001, pp. 2-3). It is obvious that formal regional cooperation is not a precondition for de facto integration. The institutional integration can follow the natural market-led processes, which is typical for Asia. ${ }^{5}$ In general, there could be a dynamic interaction between formal and market-led integration, provided that: “... economic structures evolve in a way that allows the creation of cross-border linkages, and that cooperation takes the form that is the most appropriate for addressing the most binding constraints on fuller integration..." (UNCTAD, 2007b, p. 43).

Before the 1997 Asian financial crisis, there was an emphasis on unilateral, non-discriminatory liberalization under the General Agreement on Tariffs and Trade (GATT) Uruguay Round agreements. After the crisis, major economic and political changes in Asia have occurred. There was a significant loss of confidence in South-East Asia's economic dynamism. Asian countries have also recognized that they need some form of regional framework to complement or support the functions of the International Monetary Fund (IMF). They have been criticising the IMF for its failure in addressing the financial crisis. ${ }^{6}$ After the crisis, many countries have started economic and structural reforms to attract foreign investments and overcome the crisis, which became one of the important driving forces behind free trade agreements promotion (Yoshida, 2004, p. 11).

Another strong integration impulse was the boom of the Chinese economy and the growing rivalry between China and Japan in many areas. In 2001, China became a member of the World Trade Organization. In 2002, it agreed to form the FTA with the ASEAN (see below) between 2010 and 2015. It has also started to negotiate many FTAs with Asian and other countries (e.g. Chile, Pakistan, Australia and New Zealand, Gulf Cooperation Council). Similarly, Japan has not participated in any preferential trade agreement until 2002. Nowadays, Japan cannot afford to stand outside any sort of South-East Asian integration, which could become a platform for Chinese power. Yamazawa (2004, p. 13) calls this process "competitive liberalization", which means that: "if a certain number of economies form a group and reciprocally open up their markets and ease regulations within it, outside nations that fear discriminatory treatment will have an incentive to join the group or form

5 For example, the ASEAN was created as a political rather than economic grouping. However, trade among its participants has consistently increased since the mid-1970s. Trade liberalization was formalized only in 1992 with the launching of the ASEAN Free Trade Area (AFTA). The trade expansion and increasing economic cooperation has been induced largely by the development of a wider regional production network among the countries (driven especially by Japan, China, the Republic of Korea and Taiwan).

6 In 1997, Japan proposed foundation of the Asian Monetary Fund (AMF) to prevent another currency and financial crisis. However, this proposal was refused by the United States and China. In 2000 the ASEAN+3 countries agreed to a currency swap mechanism, so-called Chiang Mai Initiative. This agreement is designed to supplement emergency loans from the IMF and World Bank by improving regional cooperation. 
different free trade group". As regional economic integration is very difficult to resist, Baldwin (2003, p. 7) and other authors use the term domino effect: "The establishment of one regional arrangement can tip the political balance elsewhere towards pro-integrationist forces, thus reinforcing efforts to join existing arrangements or to form parallel arrangements with other excluded nations. This should cause trade barriers among members to fall (like dominoes) quite independently of multilateral negotiations." The realization of proposed Japan-Korea Free Trade Agreement ${ }^{7}$ (or a Korea-US FTA) would certainly trigger another round of domino effect, since China will face possibility of some discrimination in two of the three largest economies of the region. Among others, the fast development of regionalism and the success of the Asian countries in international markets have been contributing to deeper engagement by other countries in both regional initiatives and the multilateral trading system. Also many developing countries fear of exclusion from major markets. Thus, the competitive liberalization in Asia has been provoking the further expansion of regional cooperation and liberalization in other parts of the world economy.

It is evident that regionalism trends in South-East Asia are changing rapidly. Many new initiatives cover an ever-increasing portion of the region. According to the Asia Regional Integration Centre's statistics, 198 FTAs have been concluded in the entire Asia-Pacific region (till June 2007), of it 154 bilateral FTAs and 44 plurilateral FTAs. Thus, there is a strong preference for bilateral agreements. In 2000, there were only 27 bilateral FTAs in the Asia-Pacific region (ARIC, 2007).

\section{Chart 1: Consolidation and Integration in Asia}

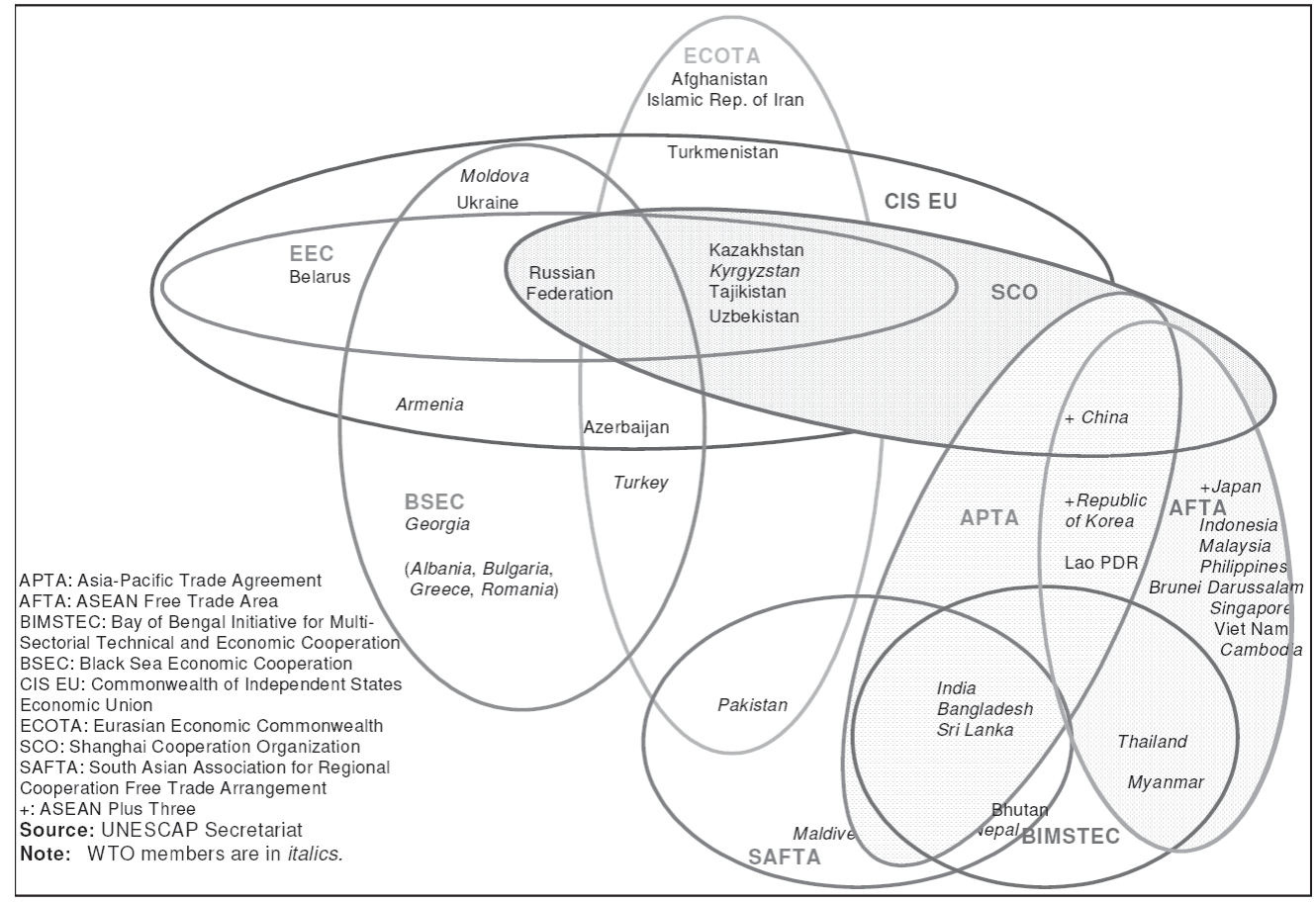

Source: UNESCAP (2007).

7 The FTA was proposed in 2002. The negotiation on bilateral Economic Partnership Agreement was launched in 2003. In 2004 it was stopped because of political tensions between the two countries. 
All Southeast Asian countries are members of at least one preferential trade agreement ${ }^{8}$ and many countries are very active in negotiating new arrangements as well. Singapore and Thailand lead the region with 20 preferential trade agreements in force and 10 agreements under negotiation, and 17 and 2 FTAs, respectively. The number of China's agreements is growing rapidly. Today, it has 9 trade agreements in force and 3 agreements under negotiation. Japan is still relatively sluggish in negotiating new partnerships; it has only 6 preferential agreements in force and 5 agreements are under negotiation (APTIAD, 2007).

\subsection{Features of current South-East Asia regionalism}

In 2003, Baldwin (2003, p. 1) wrote: "regionalism has not really started in East Asia." In 2007, the same prestigious author $(2007$, p. 6) pointed out that in spite of figures and statistics: “... there is no real regionalism in East Asia ... Regionalism means preferential trade liberalization, or discriminatory trade liberalization, because preference is just another word for discrimination. By that definition, there is not yet any real regionalism in East Asia." Baldwin has explained this situation with the fact that no serious discriminatory tariff cutting has been done in the Asian multilateral trade agreements (e.g. in the ASEAN).

From the standpoint of the regionalism theory, the shallow ${ }^{9}$ and South-South ${ }^{10}$ integration schemes dominate in South-East Asia. Until recently, Asian countries have preferred preferential or free trade agreements in terms of trade in goods. However, the newly concluded agreements go beyond reduction of elimination of tariffs and non-tariff barriers of trade. They also contain provisions on free trade in services and capital; common rules and provisions concerning other areas (e.g. intellectual property protection, harmonization of competition policies, anti-dumping measures and safeguards etc.). After the Asian financial crisis, region's economies have accelerated monetary and financial cooperation as well. ${ }^{11}$ The formation of the 'East Asian Monetary Union' is often discussed, but still very premature (see e.g. Tan Nuo Ing, 2003).

The Asian FTAs have been mostly market-oriented, not-binding (flexible) and their decision-making style has been consensual. It is often discussed whether the EU type of regional integration is feasible in South-East Asia. The weak institutionalisation and different conditions for regionalism makes it difficult to create a deep integration like that in

8 According to the APTIAD (2007), "preferential trade agreement" is any process of trade integration by which participating countries extend full or more often partial reciprocal trade concessions. The term 'preferential' signals the fact that members of such agreements are entitled (by virtue of GATT Article XXIV or GATS Article V) to grant each other preferences that are not compulsory to extend to other WTO members. Historically, PTAs were concluded between countries of the same geographical region leading to the use of the term 'regional trade agreements'.

9 'Shallow regionalism' stands for reduction or elimination of border barriers to trade. This term contrasts with 'deep integration' that involves intergovernmental cooperation in designing and applying domestic policies such as taxes, health and safety regulations, environmental and labour standards and qualification standards. It may involve either harmonization of policies of mutual recognition.

10 South-South agreements are concluded among developing countries; usually under the GATT/WTO Enabling Clause which allows for differential and more favourable treatment accorded to developing countries, bearing in mind their development objectives. Such agreements may include partial scope agreements with limited trade concessions or fully fledged free trade agreements or customs unions. There are only few WTO Article 24-based FTAs in South-East Asia, e.g. between Japan and Singapore. These agreements have to cover 'substantially all' goods within 10 years.

11 In 1997, Japan proposed foundation of the Asian Monetary Fund (AMF) to prevent another currency and financial crisis. However, this proposal was refused by the United States and China. In 2000, the ASEAN +3 countries agreed to a currency swap mechanism, so-called Chiang Mai Initiative. This agreement is designed to supplement emergency loans from the IMF and World Bank by improving regional cooperation. 
Europe (see e.g. Stuchlíková, Hnát, 2007). On the other hand, some of the new FTAs contain also binding rules, which is quite a new trend.

According to some authors (Cihelková et al., 2007; Bergsten, 1997), the Asian regionalism is mostly 'open'. In general, RTAs can function as complements to the multilateral trading system; they can help to build and strengthen in. On the other hand, RTAs are discriminatory as they break the MFN principle. Thus, the open regionalism concept tries to achieve compatibility between the regional integration and multilateral integration in the WTO to assure that: "... regional agreements will in practice be building blocks for further global liberalisation rather than stumbling blocks and deter such progress" (Bergsten, 1997, p. 545). Open regionalism is basically a strategy of unilateral trade liberalisation within the RTA with the extension of its benefits to non-member countries on the basis of the MFN principle. The concept was adopted by the Asia Pacific Economic Cooperation (APEC) for the first time in 1989. In the region of South-East Asia, especially the ASEAN+3 (see bellow) has inherently open character. Lee and Park (2006, pp. 101-102) suggest that creation of a regional trading block in the region is expected to: "... contribute to a worldwide institutional framework of multilateralism ... The evolution of ASEAN+3 into a formal trading agreement would further promote and reinforce both intra-regional trade and inter-regional trade." The ASEAN +3 should not diverge from the principles of open regionalism and multilateralism. ${ }^{12}$

As noted above, Asian countries prefer bilateral FTAs (this process is called 'economic bilateralism'). ${ }^{13}$ However, a number of bilateral agreements has been growing very fast around the whole world economy. The United States have 9 bilateral free trade agreements in force; other 9 bilateral agreements are negotiated or pending congressional approval (as of December 2007). The European Union has been concluding many bilateral FTAs as well. In general, bilateral agreements are much easier to arrange and often more effective than multilateral agreements. Especially, insufficient progress of the WTO talks during the Doha Development Agenda (2001-2007) has led to further promotion of bilateralism in the world. Bilateral agreements may also play a new role in mitigating the effects of the large RTAs. Nevertheless, some authors warn against prevailing negative effects of bilateralism. According to Dent (2006, p. 82), "region-convergent bilateralism can make positive contributions to the development of regionalism, whereas region-divergent bilateralism undermines community-building endeavors. " Region-convergent agreements may stimulate other states to conclude similar partnerships; as bilateral FTAs may be rationalized into one unified multilateral FTA. On the other hand, region-divergent agreements may lead to hazardous inter-state rivalry; their objectives and actions may be inconsistent with those of regional organizations. Also the WTO is a great opponent of bilateralism in the world trade today. Its Director-General Pascal Lamy warns against bilateral agreements that may be a boon in the short term, but they are a stumbling block to trade in the long run.

There are only few multilateral integration schemes in the region of South-East Asia. The Association of South-East Nations (ASEAN) is the oldest and the most important integration organization in the region. Until the 1990s, it was limited mostly to regional cooperation on political and security issues. In 1992, member countries agreed to establish the

12 Using a modified gravity equation (by explicitly introducing import tariffs), Lee and Park (2006) examined whether any regional trading blocks are forming in East Asia. They found that ASEAN +3 showed a significant intra-regional trade bias in all tested cases. Moreover, they found that the United States and Japan exerted special effects on ASEAN+3, promoting intra-regional trade.

13 Most bilateral trade agreements (BTAs) are between two countries. A BTA can also be signed between other types of political entities, e.g. between a country and a regional trade grouping or between two RTAs. Bilateral agreements are mostly concluded as free trade agreements. They can take the form of custom union or a service agreement. The nature of the agreement may vary in many ways - see Hnát (2007). 
ASEAN Free Trade Area (AFTA) through a Common Effective Preferential Tariff scheme by 2010 or 2015. In spite of delays and weak results, the ASEAN leaders agreed (Bali Concord II) to achieve a single market by creating the Asian Economic Community (AEC) by the year 2020. Many authors (e.g. Kikuchi, 2006, p. 42) suggest that the ASEAN is "now coming back to the central stage of regional institution building in South-East Asia. "It extends its relations and FTAs with other countries through the ASEAN $+\mathrm{X}$ institutional arrangements. Nowadays, there exist ASEAN+1 (India and Russia, respectively), ASEAN +2 (Australia and New Zealand) and ASEAN+3 (China, Japan and Republic of Korea) dialogues. As stated above, ASEAN +3 is open to the trade with the rest of the world (i.e. there is no trade diversion, see Lee and Park, 2006). The regional trade agreement among ASEAN +3 countries would help to stabilize the existing ties among the region's countries; it would be likely the building block for a possible establishment of an East Asia Free Trade Area (EAFTA) in the future.

There are many problems and obstacles concerning Asian regionalism. From the sectoral point of view, agriculture is a central problem in majority of regional initiatives. For many developing countries of South-East Asia, agriculture still represents a major source of employment. Thus, there is general consensus that it should be treated apart. However, in the future, it would be in the interest of almost all countries to include agriculture in FTAs agreements.

Also the quickly spreading, multiple overlapping membership in preferential trade agreements in South-East Asia ('Asian Noodle Bowl Syndrome' or 'Spaghetti Bowl Effect' - see Chart 2) raises a number of issues. It can result in the duplication and unclear tariff concessions and rules of origin. The possible trade disputes between some countries have the potential to cause problems for trade relations of the others. Moreover, it raises the cost of negotiating, implementing and administering FTAs. Baldwin (2007, p. 18) suggests that the Noodle Bowl Syndrome is a source of extreme interdependence and fragility in the region's regionalism processes. The overlapping membership makes an obstacle for effective functioning of new, modern and progressive FTAs. Thus, it is necessary to consolidate the existing agreements at an accelerated pace.

It may be useful to rationalize and consolidate bilateral partnerships into wider integration schemes. According to Kikuchi (2006, p. 52), the region also needs "agreed norms and principles to promote much deeper collaboration to respond various challenges." South-East Asia will have to institutionalise the framework to a certain degree, and solve the leadership problem (China versus Japan) as well as many other dilemmas in the regionalism strategies. 


\section{Chart 2: Noodle Bowl Syndrome in South-East Asia}

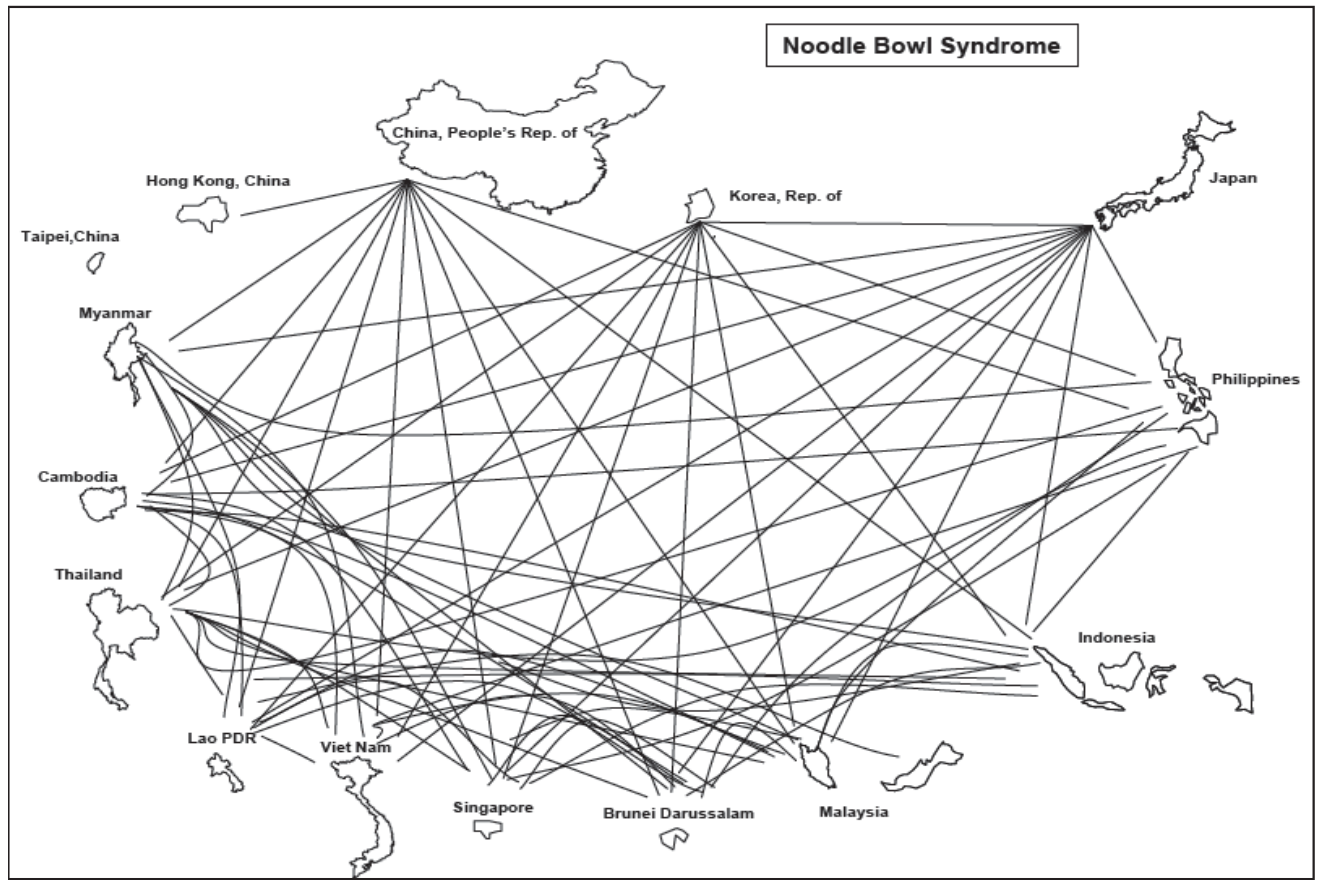

Note: The map shows FTAs signed or under negotiation as of January 2006. East Asia is defined here as the 10 members of ASEAN, PRC, Japan, and Korea.

Source: Baldwin (2007, p. 5).

The ASEAN is in a unique position of the hub of a whole series of proposed preferential agreements in the region today. The mentioned proposal of the East Asian Free Trade Area (EAFTA) was set in 2000, at the ASEAN+3 Summit. It is evident that the ASEAN+3 processes would be the main vehicle for achieving an East Asian Economic Community (EAEC) covering the whole region. However, many authors (e.g. Lee, Jeong, Kim and Bang, 2006, p. 107) suggest that there are many obstacles to the EAFTA. Besides the huge diversity among Asian countries, growing economic rivalry between China and Japan, it is the lack of community spirit in the region (and namely in North-East Asia). However, if such regional-wide integration is achieved, South-East Asia could become one of the world's most powerful economic areas. Yet, the formation of a new, integrated economic system will be probably very gradual. It will result 'from evolution, not revolution' (Yamazawa, 2004, p. 28).

South-East Asia is also expanding its cooperation with non-Asian countries. The Asia-Europe Meeting (ASEM) is an important example of a trans-regional, multilateral economic forum. ${ }^{14}$ It is aimed at closer trade and other economic cooperation between Asia and Europe. For the time being, ASEM has no strong institutional structure, coordination mechanisms nor binding rules. Nevertheless, according to some observers, ASEM activi-

14 ASEM is an informal process of political, economic and socio-cultural dialogue and co-operation established in 1996, bringing together individual EU member states plus the European Commission with Asian countries (Brunei, Cambodia, China, Indonesia, Japan, Korea, Laos, Malaysia, Myanmar, Philippines, Singapore, Thailand, Vietnam, India, Mongolia and Pakistan). 
ties could be a catalyst for consolidating the South-East Asia regional community in the coming years. ${ }^{15}$

\section{Japan position towards regionalism in South-East Asia}

The Japanese government has begun shifting the stress in the trade policy from multilateralism to bilateralism (more generally to regionalism) since the late 1990s. In the past, there have been many reasons for negative and indecisive attitudes of Japan toward economic integration both inside and outside of Japanese economy.

\subsection{Some factors behind the changing Japanese regional politics}

Japan has been one of the most significant promoters of the multilateral trade system. Japan's post-war trade policy has been based on the GATT/WTO, and the principle of most-favoured nation (MFN) treatment. The idea has been that to join regional trade agreements would impose discriminatory conditions on countries outside the region and be considered inconsistent with the WTO principles of free, non-discriminatory trade. However, negotiations during the Uruguay Round and Doha Development Agenda were very complicated and protracted. With the growth in the number of WTO members (151 countries as of December 2007), the consensus-based decision-making process has lost effectiveness. Insufficient progress of the multilateral talks has led to further softening of Japan's opposition towards regional economic integration. Japan still promotes maintaining and strengthening of the multilateral trade system under the WTO. It is one of the five priorities of current Japanese economic diplomacy. However, regional economic partnerships 'complement' the multilateral liberalization, which is a new element (MOFA, 2006).

For many years, Japan has been enjoying high economic growth rates and improving conditions in many areas. The expansion of exports gave the Japanese economy good prospects. Thus, it did not feel any need to secure markets with its main partners through (even positively) discriminatory FTAs. The Japanese economy had flourished until the beginning of 1990s when the bubble economy collapsed. Economic stagnation throughout all of the 1990s has caused concerns for Japanese business and investments activities in Asia. Moreover, Japan has been losing its economic dominance in the region, especially in favour of China. Since Japan has lost the economic dynamism, it has had to take advantage of the dynamism of its fast growing neighbours.

Japan's attitudes towards FTAs had also much to do with domestic politics and pressure of interest groups, mostly from some industries and agriculture. The policymaking process in Japan is dominated by elite bureaucrats who pursue public interests. Politicians in the ruling Liberal Democratic Party (LDP) seek to use government policies in order to protect interests of major constituencies. But the LDP's opposition to FTAs has softened due to slow liberalization under the WTO. The LDP began to stress linkages with South-East Asia and to consider FTAs as necessary for counterbalancing growing China's influence. Of course, the LDP position towards FTAs has resulted from the evolving interest groups' general interests in approving FTAs and promoting exports to South-East Asia.

As mentioned above, evolving trade, financial and other networks have led to increased economic interdependence in South-East Asia. Asian countries did not seek for any for-

15 Southeast Asian countries participate in Asia-Pacific Economic Cooperation (APEC) that is also very dynamic economic forum for facilitating economic growth, cooperation, trade and investment in the Asia-Pacific region. It was established in 1989 and nowadays, it has 21 members. 
mal economic cooperation until the 1990s. Japan found it necessary to promote loose Asia-Pacific regional cooperation rather than FTAs. After the 1997 Asian crisis, there was an important loss of confidence in South-East Asian economic dynamism. Japan was not seriously affected by the financial crisis, but it played an active role in providing rescue funds for countries in distress. This support was appreciated, and contributed to the lessening of previous antipathy toward Japanese leadership in Asia and to a gradual increase in Japanese influence in South-East Asia. It was a natural outcome that Japan's connections to other South-East Asian countries have grown stronger. Moreover, Japan has become "more flexible toward and tolerant of East Asian regionalism in contrast to its stance toward Asia-Pacific regionalism" (Yoshida, 2004, p. 11).

Despite the absence of economic integration at institutional level, the South-East Asian region has the world's highest rate of growth in intra-regional trade. From the perspective of Japan, South-East Asia is not merely an export destination, but it is an increasingly important source of imports. The expansion of economic relations between Japan and the South-East Asian countries in the 1990s increased Japan's participation in the Asian regionalism.

And last but not least, China's growth is another factor for changes in Japan's position towards regionalism. China is an economic danger as well as an opportunity for Japan. For the time being, the two economies are mostly complementary, with Japan concentrating on electronics, engineering and vehicle industries (i.e. high-tech products) and China occupying the cheaper industries. China's rapid growth has changed Asia, and it is also changing Japan's diplomacy, especially in the trade, security and energy policy. Japan and China compete for the initiative in South-East Asian regionalism as well (Stuchliková, 2007).

\subsection{Contemporary Japan's FTA/EPA Strategy}

The changing situation in the world economy has raised awareness of regional integration in Japan. Its policies have shifted from hesitation to promotion of FTAs. The Ministry of Foreign Affairs (MOFA) adopted the first FTA Strategy in 2002. According to the Strategy, FTAs should represent a 'complement' to liberalization within the WTO. The Strategy stresses the importance of FTAs with South-East Asia and countries where high trade barriers exist. Policy to Strengthen Economic Partnership (2002) proposed the formation of East Asian Business Zone. MOFA marked out FTAs as the main instrument to strengthen economic and political relations with Asian countries.

In 2004 Prime Minister Koizumi confirmed the necessity of FTAs with respect to structural reforms in progress. This stance was further strengthened by the Basic Policy towards further promotion of EPAs. It identified criteria on countries to negotiate with on the EPAs: 1) creation of beneficial international environment; 2) attainment of economic interests of Japan; 3) taking into account the situation of the partner and feasibility to realize EPA/FTA. So far the last, Globalization Strategy (2006) aims at enhancing Japan's international competitiveness. It includes a wide range of proposals to increase benefits from globalization, among them goals concerning the Japan's FTA strategy. Japan is concentrated to accelerate negotiations on EPAs, which is expected to expand the share of trade with EPA partners to $25 \%$ by 2010 .

Japan prefers complex FTAs, called Economic Partnership Agreements. EPAs cover trade in goods, services, investment, and movement of people and provide for cooperation in finance etc. The first Japan's EPA was signed with Singapore (2002). Pursuant the GATT Article 24, this EPA covered 'substantially all trade', including mutual agricultural trade (which is insignificant). In fact, it has been rather an experiment in the overall process 
of the Japan's policy shift. Negotiations with other South-East Asian countries have been rather complicated because of agricultural trade, which is sensitive and protected sector in Japan.

Until now (as of December 2007), the Japanese government have concluded many other (mostly bilateral) EPAs with South-East Asian countries: Malaysia (the agreement was signed in 2005), the Philippines (2006), Brunei (2007), Indonesia (2007) and Thailand (2007). Other bilateral EPAs are under negotiation or scheduled to be launched (Republic of Korea, Vietnam) and studied. South-East Asian consumer markets are expected to continue growing as a result of further economic growth in the region and the emergence of a middle class characterized by relatively high incomes and consumer spending. This could further intensify the intra-regional trade in the region.

After first concentrating on FTAs with neighbouring countries, Japan has expanded their scope to include Mexico (the agreement was signed in 2004), Chile (2007), India (the negotiation was launched in 2007), Australia (2006) and Switzerland (2007). The main objectives include expanded business opportunities and ensuring stable supplies of resources. Countries and regions with which Japan has concluded, is negotiating or is considering an EPA account for $32 \%$ of the country's total trade (JETRO, 2007, p. 1).

Japan also aims to deepen the cooperation with multilateral organizations, especially Asia-Pacific Economic Cooperation (APEC), Association of Southeast Asian Nations (the negotiation on economic partnership was launched in 2005) or Gulf Cooperation Council (GCC). ${ }^{16}$ Japan takes part along in the ASEAN+3 cooperation and in ASEM.

Although both Japan and China are seeking FTAs with the ASEAN and other Asian countries, neither Tokyo nor Beijing has proposed a bilateral Japan-China free trade agreement. ${ }^{17}$ Such agreement could bring significant gains for both countries because of their geographical proximity, the size of the two economies and mutual trade flows. In 2004, the JETRO established a joint research group with a Chinese government institute to examine the possible impact of bilateral agreement on both economies. There are also governmental talks concerning the economic partnership. Though, there is not yet a strong political will and sufficient public support to form the FTA between Japan and China, especially from the Japan's point of view.

As shown by Wall (2002, p. 132), Japan's reluctance towards regional economic integration may have had significant effects on its pattern and volume of trade. Japanese exports have been reduced by the regional integration of its trading partners. In 2002, the (Japanese) Ministry of Finance Policy Research Institute investigated the most important macroeconomic effects of FTAs on the Japanese economy. Calculating the economic effect of the FTAs indicates that for ASEAN+3 under FTA, Japan could grow on average 1.02 percentage points faster annually until 2010. However, if a FTA between China and ASEAN that excludes Japan and Korea goes into effect, Japan's GDP could drop by 0.05

16 The GCC was established in 1981. Today it has 6 member states: United Arab Emirates, Bahrain, Saudi Arabia, Sultanate of Oman, Qatar and Kuwait. In the economic area, the GCC has created a customs union among the member states (with some exceptions in trade in goods). It proposes to deepen the integration process and establish a common market and monetary union. Japan depends on the Middle East for approximately 80-90\% of its crude oil imports (MOFA, 2006). Therefore, it is vital for Japan to ensure peace and stability in the region and maintain good relations with the GCC countries.

17 In 2004, ASEAN and China agreed to establish the ASEAN-China Free Trade Area (ACFTA) by 2010 for the original six ASEAN members and China, and by 2015 for the newer ASEAN member states. ACFTA can be negotiated under the GATT/WTO enabling clause. In contrast, Japan-ASEAN FTA must be notified under the GATT Article XXIV and must cover substantially all bilateral trade. Therefore, China could advance faster than Japan in its negotiations with the ASEAN. 
percentage points (Ministry of Finance of Japan, 2002). From this point of view, Japan should take more positive attitude to dealing with FTAs.

In 2003, Kawasaki (2003) worked out a quantitative simulation analysis on the impact of Japan's FTA in Asia using a Computable General Equilibrium (CGE) model of global trade. ${ }^{18}$ The relative significance of bilateral and regional trade liberalization was investigated in comparison with multilateralism. The result of this study suggests that the static gains from the existing or planned agreements are positive but extremely small at around $0.1 \%$ of GDP. Japanese macroeconomic gains measured in terms of rates of change in real GDP were the highest in the case of a hypothetical Japan-China FTA ( $0.45 \%$ of GDP). On the contrary, concluded FTAs with the Philippines, Malaysia and Indonesia have virtually no impact on the Japanese GDP $(0.03 \%$, respectively $0.08 \%$ and $0.06 \%$ of GDP).

Japanese trade balances are generally deteriorating with the exception of Japan's FTA with Malaysia and the Philippines. Moreover, EPAs with major trading partners would likely be accompanied by reductions of $1-4 \%$ in Japan's agricultural production. "The rates of change in trade, production and capital formation are shown to be significantly larger in six Asian countries compared with that of Japan" (Kawasaki, 2003, p. 10). The consequent studies (Jones, Yoon, 2006, p. 24) suggest that the impact from potential EPAs with Australia, China, the United States and the EU is likely to be much larger, reflecting the trade structure, market size and income level of these potential counterparts $(0.15 \%$ of GDP, $0.5 \%, 0.24 \%, 0.2 \%$ respectively).

Another way to thinking through the implications of various trade arrangements is to calculate exclusion indices. The threat of exclusion is the key to the logic driving the domino effect in regional integration. As shown by Baldwin (2003), the exclusion index for Japan for ASEAN free trade area (AFTA) + China (excluding Singapore) is about $36 \%$. This suggests that Japanese exporters would indeed care about such an FTA if it actually did lead to substantial trade diversion. However, even a well-implemented AFTA-China FTA would have limited impact on Japanese exports to the region since the goods that would be preferentially liberalised are not highly competitive with Japanese exports. On the other hand, a Japan-Korea FTA would threaten to harm exporters in China and the all of the ASEAN members with a loss of competitiveness (via trade diversion) in the Korean and Japanese markets. To avoid this, exporters based in these nations would push their governments to join the emerging FTAs. ${ }^{19}$

18 The empirical methods used to assess the impacts of FTAs can be categorized under three groups: trade indices, gravity models, and computable general equilibrium models. The trade index approach involves the use of static measures of trade performance depending on the type of goods traded. Gravity models predict a positive relation between the volume of trade between two economies and the size of these economies and negative relation with respect to transaction cost. CGE models are used to assess both the ex ante and the ex post impacts of FTAs on production and trade structure, employment, consumption and welfare.

19 Exclusion indices show the extent to which various nations would care about being excluded from various trade blocs, i.e. the percentage of that nation's exports that go to the FTAs. 


\section{Conclusion}

South-East Asia started to form its regional integration schemes relatively late (in the second half of the 1990's). However, the current pace of regional development seems to be very fast due to many internal and external factors. Since the late 1990's, it has often been discussed whether the European Union type of regional integration is feasible in Asia. In that respect, the South-East Asian countries are not yet mature enough to adopt the European type of mostly deep and highly institutionalised integration. Paradoxically, some observers warn against regionalism in South-East Asia. New bilateral free trade agreements are criticised as inconsistent with the APEC Bogor goals and with the most-favoured-nation principle of the World Trade Organization. Thus, they may erode APEC's fragile efforts for liberalization, and will impede liberalization efforts under the WTO.

In my opinion, forming a comprehensive free trade agreement in the entire South-East Asia could serve as a testing tool whether the prevailing domestic resistance against trade liberalization can be broken through and thus this agreement can contribute to the preparation for liberalization under broader, multilateral frameworks such as APEC or the WTO. However, it is necessary to consolidate the existing integration schemes to eliminate the negative effects of the expanding and complicating Noodle Bowl syndrome in the region. The ASEAN $+X$ initiatives appear to be a corner-stone for enhanced economic and political cooperation in the near future. In this context, the nature of relationship between Japan and China will be vital for any form of deeper integration in South-East Asia.

Japan's position towards regionalism in the world has been changing very fast. In the late 1990s, Japan began to place high emphasis on a multi-layered external economic policy that utilizes various approaches. Japan should pursue free trade agreements with more Asian and non-Asian countries and regions actively if it is to remain a leading player in the global economy. Since Japan has lost the economic dynamism, it could take advantage of the dynamism of its neighbours. Nevertheless, it is necessary to deepen the integration, especially in respect to labour movement. Japan will have to accept labour inflows from South-East Asian countries due to its low birth rate and aging population. Japan should also open its agricultural markets, which would be beneficial for other Asian nations that have large agricultural sectors. Wider trade liberalization in terms of coverage of both regions and sectors would be probably more beneficial for all the potential FTAs members. 


\section{References}

ADB (2007). Asian Development Outlook 2007 - Growth Amid Change. Hong Kong, The Asian Development Bank (ADB)

ARIC (2007). FTA Trends. Asia Regional Integration Centre.

APTIAD (2007). Glossary. Asia-Pacific Trade and Investment Agreements Database.

BALDWIN, R. E. (2007). Managing the Noodle Bowl: the Fragility of East Asian Regionalism. Working Paper, No. 7, Asian Development Bank.

BALDWIN, R. E. (2003). East Asian Regionalism: A Comparison with Europe. Geneva, Graduate Institute of International Studies.

BERGSTEN, C. F. (1997). Open Regionalism. The World Economy, Vol. 20, No. 5.

CIHELKOVÁ, E. et al. (2007). Nový regionalismus - teorie a př́padová studie (Evropská unie). Praha, C. H. Beck.

DENT, Ch. (2006). The New Economic Bilateralism in Southeast Asia: Region-Convergent or Region-Divergent? International Relations of Asia-Pacific, Vol. 6, No. 1.

ESCAP (2007). Economic and Social Survey of Asia and the Pacific 2007 - Surging Ahead in Uncertain Times. New York, United Nations.

GILL, I.; KHARAS, H. (2007). An East Asian Renaissance: Ideas for Economic Growth. Washington, The World Bank.

HNÁT, P. (2007). Bilaterální regionální integrace v Evropě a Asii: vliv na regionální a světový obchodní řád. In Současná Evropa a Česká republika, No. 1.

JETRO (2007). White Paper on International Trade and Foreign Direct Investment. Tokyo, JETRO.

JONES, R. S.; YOON, T. (2006). Strengthening the Integration of Japan in the World Economy to benefit more fully from Globalization. WP No. 526, Paris, OECD.

KAWASAKI, K. (2003). The Impact of Free Trade Agreements in Asia. Tokyo, RIETI, 2003.

LEE, Ch. S.; PAR, S. Ch. (2006). An Examination of the Formation of Natural Trading Blocs in East Asia. Asian Economic Papers, pp. 90-103.

MOFA (2006). Diplomatic Bluebook 2006. Tokyo, 2006.

Ministry of Finance of Japan (2002). New Economic Prospects in Asia Research Committee Report (Press Release). Tokyo.

MUNAKATA, N. (2001). Evolution of Japan's Policy toward Economic Integration. RIETI Discussion Paper Series 02-E-006, Tokyo, RIETI.

NAKAMURA, T.; SHINAHARA, T. (2007). External Aspects of East Asian Economies and Finance - in light of growing interest in regional integration. Tokyo, Bank of Japan.

PANGESTU, M. (2006). Visions of East Asia: Three Engines for a Way Forward. In East Asia Visions: Perspectives on Economic Development. Washington, The World Bank.

STUCHLÍKOVÁ, Z.; HNÁT, P. (2007). Regionalism as a Part of Regional Governance: Europe and South-East Asia. WP No. 3, Prague, University, of Economics. 
STUCHLÍKOVÁ, Z. (2007). Multilateralism and New Regionalism: Changing Japans Approach in the Global Context. In NĚMEC, J. (ed.). Global and Regional GovernanceEurope and Beyond. Prague, Nakladatelství Oeconomica, 2007, pp. 56-75.

TAN NUO, J. (2003). The possibility of an Asian monetary union drawing form the EMU experience. In Asia Europe Journal, pp. 371-401.

UNCTAD (2007a). Handbook of Statistics 2006-2007. Geneva, United Nations Conference on Trade and Development.

UNCTAD (2007b). Trade and Development Report 2007. New York and Geneva, United Nations Conference on Trade and Development.

UNESCAP (2007). Regional Trade Agreements - Axes of Consolidation and Integration in Asia. UNESCAP, 2007.

WALL, J. H. (2002). Has Japan Been Left Out in the Cold by Regional Integration? Monetary and Economic Studies. Tokyo, Bank of Japan.

YYMAZAWA, I. (2004). Japan and the East Asian Economies: Prospects and Retrospect in the Early Twenty-First Century. WP No. 1, IDE APEC Study Centre.

YOSHIDA, T. (2004). East Asian Regionalism and Japan. WP No. 9, IDE APEC Study Centre. 


\title{
Změny v regionalismu v jihovýchodní Asii: vybrané teoretické a praktické aspekty
}

\author{
Zuzana Stuchlíková
}

\begin{abstract}
Abstrakt
V poslední době se vede řada diskusí o možných dopadech regionalismu na mnohostrannou liberalizaci obchodu. Jejich závěry jsou ovšem různé. Nicméně je zřejmé, že regionální obchodní dohody čím dál víc mění mezinárodní obchod. Děje se tak zvláště od druhé poloviny 90. let minulého století. Region jihovýchodní Asie se začal vice zabývat takovou spoluprací až po asijské finanční krizi z roku 1997. Zejména př́íklad Japonska ukazuje, jak asijské vlády změnily svůj prrístup k mezinárodní ekonomické spolupráci. Důraz částečně přesunuly z multilaterálních jednání pod hlavičkou WTO k regionálním a dvoustranným dohodám. Ovšem i přes rychlé tempo jejich uzavírání je proces regionalismu v jihovýchodní Asii stále na začátku. Teprve se uvidí, jestli asijské země zůstanou pouze na úrovni širších dohod o volném obchodu, nebo budou následovat evropského př́kladu hluboké ekonomické a politické integrace.
\end{abstract}

Klíčová slova: regionalismus; obchodní dohody; integrace.

\section{Changing Regionalism in South-East Asia: some theoretical and practical aspects}

\begin{abstract}
There are many sophisticated discussions about the possible effects of the regional economic cooperation. Their results have been ambiguous. However, it is evident that regional trade agreements (RTAs) have been increasingly transforming international trade, especially since the second half of the 1990s. The region of South-East Asia has become more interested in such cooperation only after the Asian financial crisis in 1997. Especially the case of Japan proves how the Asian governments have changed their approach to the international economic cooperation. They shifted the emphasis from the multilateral negotiations under the umbrella of the WTO to regional and bilateral agreements. However, despite its fast pace the process of regionalism in South-East Asia is still at the very beginning. It remains to be seen whether the Asian countries will stay on the level of broader FTAs or whether they will follow the European example of a deep economic and political integration.
\end{abstract}

Keywords: regionalism; trade agreements; integration.

JEL classification: F02, F13, F14, F15, F52, F53, F59. 